\title{
Effect of Organic and Inorganic Mulching on Soil Microbial Population in Acid Lime (Citrus aurantifolia Swingle)
}

\author{
Esther Lalruatsangi ${ }^{*}$, B.N. Hazarika ${ }^{1}$ and P. Raja ${ }^{2}$ \\ ${ }^{1}$ Department of Fruit Science, ${ }^{2}$ Department of Plant Protection, College of Horticulture and \\ Forestry, Central Agricultural University, Pasighat, Arunachal Pradesh, India \\ *Corresponding author
}

\begin{tabular}{|c|c|}
\hline & A B S T R A C T \\
\hline $\begin{array}{l}\text { Ke y w o r d s } \\
\text { acid lime, Organic } \\
\text { mulching, Inorganic } \\
\text { mulching, Soil } \\
\text { microbial } \\
\text { population }\end{array}$ & \multirow{3}{*}{$\begin{array}{l}\text { An experiment was conducted at Fruit Research Farm, College of Horticulture and } \\
\text { Forestry, Pasighat, Arunachal Pradesh to study the effects of organic and inorganic } \\
\text { mulching on soil microbial population in acid lime using Randomized Block Design. The } \\
\text { study revealed that the microbial population of the soil was found to be highly significant. } \\
\text { The highest microbial population count for bacteria was observed in paddy straw mulch } \\
\left(83.45 \times 10^{5} \mathrm{cfu} / \mathrm{g}\right) \text { followed by rice husk mulch }\left(74.88 \times 10^{5} \mathrm{cfu} / \mathrm{g}\right) \text { and minimum was } \\
\text { found in control }\left(14.06 \times 10^{5} \mathrm{cfu} / \mathrm{g}\right) \text {. Likewise, the highest microbial population count for } \\
\text { fungi was observed in rice husk mulch }\left(119.34 \times 10^{5} \mathrm{cfu} / \mathrm{g}\right) \text { followed by paddy straw mulch } \\
\left(54.77 \times 10^{5} \mathrm{cfu} / \mathrm{g}\right) \text {. The study revealed that organic mulching treatment has higher } \\
\text { microbial population as compared to inorganic mulches which might be due to the supply } \\
\text { of large amount of carbon which serves as a major food source for fungi and bacteria. }\end{array}$} \\
\hline Article Info & \\
\hline $\begin{array}{l}\text { Accepted: } \\
\text { 15 June } 2019 \\
\text { Available Online: } \\
10 \text { July } 2019\end{array}$ & \\
\hline
\end{tabular}

\section{Introduction}

Acid lime (Citrus aurantifolia Swingle) belongs to the family Rutaceae, having a chromosome number of $2 \mathrm{n}=18$ and is considered to be indigenous to India. It is the third important citrus fruit crop in India next to mandarin and sweet orange. The fruit is valued not only for its nutritional qualities but also for pharmaceutical, nutraceutical, cosmeceutical, medicinal and health sector with its great potential growth. Mulching plays an important role in conservation of soil moisture during dry periods, as well as improves physical, biological and chemical properties of soil. A mulch is a material placed on or spread over the soil surface to protect the soil from erosion, conserve soil moisture and suppress weed growth. Mulching is a practice, which helps in proper growth and development of the plants by modifying soil temperature, providing better 
nutrient availability and by better moisture conservation (Kher et al., 2010). Research has shown that mulch provides many benefits to crop production through soil and water conservation enhance soil biological activity and improve chemical and physical properties of the soil (Bhardwaj, 2013). However, the advantageous effects of the mulching materials on soil microbial population have not been studied in acid lime. Therefore, an investigation was done to find out the effect of organic and inorganic mulching materials on soil microbial population in acid lime.

\section{Materials and Methods}

The experiment was carried out on 6 years old of acid lime var. PKM 1 planted at spacing of $3 \mathrm{~m} \times 3 \mathrm{~m}$ at Fruit Research Farm, College of Horticulture and Forestry, Central Agricultural University, Pasighat. Arunachal Pradesh. The experiment consisted of eight treatments in a Randomized Block design with three replications. The organic mulching treatments were $\mathrm{T} 1=$ Dry grasses, $\mathrm{T} 2=$ Banana leaves, T3 = Paddy straw, T4 = Rice husk, T5 = Wood shavings, $\mathrm{T} 6=$ Saw dust while the inorganic mulching treatments are of $\mathrm{T} 7=$ Polythene mulch with black side facing upward and T8 = Polythene mulch with silver side facing upward.

\section{Estimation of microbial population}

The soil microbial population was enumerated from soil samples collected from the experimental field and were analyzed for soil microorganisms viz. bacteria and fungi using serial dilution and plating technique.. The number of colonies were counted and multiplied by the dilution factor for the concerned group of microorganisms and expressed as number of colony forming units (CFU) per gram of oven dry soil (Parkinson $e t$ al., 1971).

\section{Fungi (x $10^{5} \mathrm{cfu} / \mathrm{g}$ soil $)$}

The fungal population was enumerated by plating one ml of $10^{-5}$ dilution of the soil sample in sterile petri plates containing Potato Dextrose Agar medium. After 48 hours of incubation, the fungal colonies were counted and expressed in CFU per $g$ dry weight of soil.

\section{Bacteria (x $10^{5} \mathrm{cfu} / \mathrm{g}$ soil)}

The bacterial population was enumerated by plating one $\mathrm{ml}$ of $10^{-5}$ dilution using Potato Dextrose Agar medium. The bacterial colonies appearing on the plates after $48 \mathrm{~h}$ of incubation were counted and expressed in colony forming units (CFU) per $\mathrm{g}$ dry weight of the soil.

\section{Results and Discussion}

\section{Total fungal counts}

The microbial population count for fungi was found to be highly significant and the highest fungal count was observed in rice husk mulch $\left(119.34 \times 10^{5} \mathrm{cfu} / \mathrm{g}^{)}\right.$followed by paddy straw mulch $\left(54.77 \times 10^{5} \mathrm{cfu} / \mathrm{g}\right)$ as shown in Table 1 . The result indicates that organic mulching treatment have higher count of microbial population. Similar observations have been observed in Ammaan et al., (2019).

\section{Total bacteria counts}

The higher microbial population count for bacteria was observed in paddy straw mulch $\left(83.45 \times 10^{5} \mathrm{cfu} / \mathrm{g}\right)$ as compared to rice husk mulch $\left(74.88 \times 10^{5} \mathrm{cfu} / \mathrm{g}\right)$ as shown in Table 1. Similar report was stated by Ammaan and Subramanian (2017). The increase in microbial population of organic mulches as compared to inorganic mulches might be due to the supply of large amount of carbon which serves as a major food source for fungi and bacteria. 
Table.1 Effect of organic and inorganic mulching on soil microbial population

\begin{tabular}{|c|c|c|}
\hline Treatments & $\begin{array}{c}\text { Bacteria } \\
\left(\times \mathbf{1 0}^{\mathbf{5}} \mathbf{c f u} / \mathbf{g} \text { soil }\right)\end{array}$ & $\begin{array}{c}\text { Fungi } \\
(\times \mathbf{1 0} \mathbf{5} \text { cfu/g soil })\end{array}$ \\
\hline $\mathbf{T}_{\mathbf{1}}$ & 29.42 & 0.10 \\
\hline $\mathbf{T}_{\mathbf{2}}$ & 27.36 & 0 \\
\hline $\mathbf{T}_{\mathbf{3}}$ & 83.45 & 54.77 \\
\hline $\mathbf{T}_{\mathbf{4}}$ & 74.88 & 119.34 \\
\hline $\mathbf{T}_{\mathbf{5}}$ & 31.89 & 0.25 \\
\hline $\mathbf{T}_{\mathbf{6}}$ & 34.77 & 0.03 \\
\hline $\mathbf{T}_{\mathbf{7}}$ & 47.71 & 22.71 \\
\hline $\mathbf{T}_{\mathbf{8}}$ & 21.07 & 12.30 \\
\hline SEd $(\mathbf{\pm})$ & 1.14 & 0.18 \\
\hline CD at 5\% & 2.43 & 0.38 \\
\hline
\end{tabular}

\section{References}

Ammaan, M., A. Akila, M. Muthukrishnan, M.A. Nivedhaa, A. Rahul, B. Rishi, S.P. Sowmya, S. Sumithra, Suraparaju Deepthi and Theradimani, M. 2019. Effect of Organic Manures and Biofertilizers on Soil Microbial Population in Amaranth (Amaranthus blitum). Int. J. Curr. Microbiol. App. Sci. 8(06): 700-704.

Ammaan, M. and Subramanian, S. 2017. Efficacy of Organic Manures and Biofertilizers on Soil Microbial Count and Yield of Black Nightshade (Solanum nigrum L.). Int. J. Curr.
Microbiol. App. Sci. 6(7): 1780-1786. Bhardwaj, R.L. 2013. Effect of Mulching on Crop Production under Rainfed Condition- A Review. Agric. Rev. 34(3): 188-197.

Kher, R., Baba, J.A. and Bakshi, P. 2010. Influence of Planting Time and Mulching Material on Growth and Fruit Yield of Strawberry cv. Chandler. Ind. J. Hortic., 67(4): 441-444.

Parkinson, D., J.R.G. Gray and S.T. Williams. 1971. Methods for Studying the Ecology of Soil Microorganisms. Oxford Blackwell Scientific Publications. pp. 116.

\section{How to cite this article:}

Esther Lalruatsangi, B.N. Hazarika and Raja, P. 2019. Effect of Organic and Inorganic Mulching on Soil Microbial Population in Acid Lime (Citrus aurantifolia Swingle). Int.J.Curr.Microbiol.App.Sci. 8(07): 2062-2064. doi: https://doi.org/10.20546/ijcmas.2019.807.247 